\title{
The Kobza and the Bandura \\ A Study in Similarities and Contrasts
}

\author{
Andrij Hornjatkevyč \\ University of Alberta \\ Edmonton, Alberta, Canada
}

By introduction

In March 1992, the rural artist Levko Voiedylo exhibited in Kyiv a series of his works entitled "Гомери України [Homers of Ukraine]." These were paintings of bandura and kobza players from the past, based both on real portraits and on the artist's own imagination. By referring to his subjects as Ukrainian Homers Voiedylo intimated that they were both poets and carriers of an oral epic tradition.

Much earlier in the century, in 1900 to be exact, the scholar Ilarion Ohonovskyi published in L'viv his Словар до Гомерової Одиссеї $i$ Ілїяди [Dictionary to Homer's Odyssey and Iliad]. In this work, he translated lyre, cithara] [418]. He also translated форні́ $\omega$ аs граю на кобзї [I play the kobza]. It is quite safe to assume that neither the kobza nor bandura were known in Homeric times, neither in their present nor even in their earlier forms. Thus Ohonovskyi's translation must be taken as poetic licence. Indeed, chordophones with a pear shaped body and long neck were not known in ancient Greece. What makes Ohonovskyi's gloss even more unusual is the fact that, at the turn of the twentieth century, neither instrument was in popular use in Western Ukraine. To be sure, the words themselves may have been known for at least a century, but no one played either the bandura or the kobza in those regions. It is also telling that the words kobza and bandura are treated as synonyms but there is ample evidence that, popular usage notwithstanding, these were two distinct, albeit related, instruments. Today, the former is known in at least two forms while the latter has at least three major incarnations.

In his history of King Sigismund III (reigned 1587-1632), Franciszek Siarczyński enumerated the musical instruments used in the seventeenth century Polish Kingdom, which at that time included extensive parts of Ukraine. He listed the bandura, among urban instruments, adding that commoners played the kobza. In his detailed description of Ukraine, Aleksandr Rigel'man explicitly stated that they are two related but different instruments: 
"Many of them are fine musicians. They play primarily on violins, the double bass, hammer dulcimer, psalteries, bandura and on the lute, as well as on trumpets. Villagers in hamlets also play the violin, the kobza (a type of bandura) and on pipes, while the inhabitants of Polissya also play the bagpipe...[Book 6, ch. 38, 4: 87]. [Emphasis supplied throughout - AH]

What did these instruments look like and how did they come to be played in Ukraine? Were they imports or local inventions? Before discussing the differences between the kobza and bandura, one can state at the outset that they are plucked chordophones with a neck and a pear shaped body. Instruments of this type can be found throughout Eurasia (and beyond) from the Japanese biwa, the Chinese p'i p'a, through the sitar and tambura of the Indian subcontinent, to the ûd of Mesopotamia and far beyond, and to various lutes, theorbos and mandolins of Central and Southern Europe [Diagram Group 178-189]. What distinguishes the kobza and bandura from all those instruments is the presence of treble strings on the bellies of both, at least in their recent form.

\section{Origins}

The earliest documentation in Ukraine of an instrument from which the kobza and bandura could have evolved is an eleventh century fresco in the northwest staircase of St. Sophia Cathedral in Kyiv.

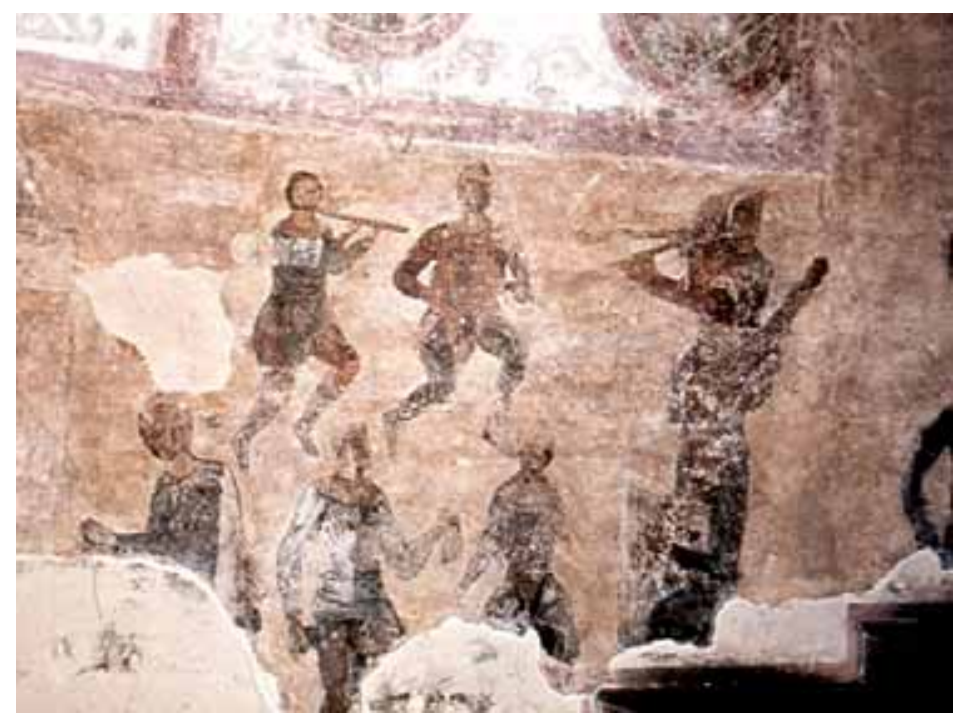

Minstrels. St. Sophia Cathedral in Kyiv, $11^{\text {th }} \mathrm{c}$. 
It depicts a group of minstrels playing various instruments and dancing. Among them we see a musician playing an instrument with a pear shaped body and long neck. He stops the strings (their exact number is extremely difficult to ascertain) with his left hand and plucks them with his right. Even this evidence is ambiguous because we cannot be certain whether the minstrels are those of the Kyivan or Byzantine court. After all, the mosaics and frescos of the cathedral were done either by Greek artists or under their direct supervision. Furthermore, we do not know the name of this instrument with any certainty [Khotkevych 66]. In a chart prepared by the author of this paper in the mid 1970s the instrument was called the "protokobza."

A possible earlier reference can be found in Theophilactus Simocatta (early seventh century). Under the year 592 he wrote about Slavs who played a musical instrument that he called a lyre:

\begin{abstract}
"On the following day three men, Sclavenes by race, who were not wearing any iron or military equipment, were captured by the emperor's [Maurice, 582-602] bodyguards. Lyres were their baggage, and they were not carrying anything else at all. ... They carried lyres since it was not their practice to gird weapons on their bodies, because their country was ignorant of iron and thereby provided them with a peaceful and troublefree life; they made music on lyres because they did not know how to sound forth on trumpets." [VI.2.10 ... 15; 160]
\end{abstract}

It must be noted, however, that the event described occurred in Thrace, immediately north of the Sea of Marmara, and although the author calls this trio "Slavs" there is no evidence that they had come from Ukrainian lands.

Closer to Ukraine and from more recent times is the testimony of the Arab chronicler Ibn Faḍlān. He describes the funerary rites of a Rus' trading expedition that had set up camp on the lower Volga.

"When they came to his grave, they removed the earth from the timbers and raised the timbers, drew him [the deceased] in the same garment in which he had died, and I saw how he had turned black from the cold earth. I also noted that they had put in his grave mead, fruits, and a kind of mandolin. They now took all of these out of the grave." [68]

While the English translator R. N. Frye uses the expression "kind of mandolin," an earlier Russian translation by A. Harkavy uses the glosses "lute (or balalaika)." One could go along with the word "lute" since it is of Arabic origin - al-' 'ūd - except that Ibn Faḍlān used the word țanbūr. 
Ibn Faḍlān's narrative must be taken with some reservation. Harkavy [114-116] cautioned that Arabic travelers were not the best ethnologists and could confuse nationalities. In this instance it is not clear whether Ibn Faḍlān was talking about Khazars, (Volga) Bulgars, Slavs, Finnic people or even Scandinavian Varangians. Indeed, merchant caravans of those times could be composed of any or even all of the above. Thus, again, we are sure of neither the nature of the instrument nor the ethnicity of the people described. Therefore, lacking any other reliable information about putative ancestors of the kobza and bandura, we must accept the St. Sophia fresco as the earliest record of an instrument in Ukraine from which the kobza and bandura could have evolved.

Ukrainian Bandurist Chorus program notes from the 1950s stated that the word "kobza" is of Turkic origin, suggesting that instrument came to Ukraine from Asia and was brought by the innumerable nomads that appeared in the Ukrainian steppes. On the other hand, the word "bandura" has European roots. This would imply that this instrument came from Central Europe. Although studying the etymology of an instrument name can be tempting, it says little about the artefact that carries that name. Let us examine the word used in different Slavic languages that can be traced to a reconstructed Common Slavic verb *godo, *gosti - "to sound." It gives Ukrainian "husli," Czech "housle," and Bosnian "gusle." We know that the Ukrainian "husli" is a kind of psaltery, the Czech "housle" is a violin, and the Bosnian "gusle" is a bowed monochord. Similarly, it can be shown that the words "guitar" and "zither" are derived from the Greek kit $\theta$ opıs. The only common element of these three instruments is that they are plucked chordophones.

There is no denying that the word "kobza" comes from Asia. Numerous Turkic languages have the words kobyz, kopuz, kobuz, kobas, qobuz, qobyz, and many others. The etymology of the word "bandura" is equally transparent. It probably came into Ukrainian from Polish because Western and Southern Europe know many instruments with a similar name; one need only mention the English bandore (more about it later), the Spanish bandurria or the Italian pandura or pandora. These can be traced to the Greek $\pi \alpha v \delta \omega \rho \alpha$, which in turn can be connected to the Old Persian țanbūr - the very word used by Ibn Faḍlān. This word, in turn, is related to Sumerian pantur/pantur which means little bow.

Ukrainian scholars often cited Aleksandr Famintsyn's quotation of the English historian John Stowe who wrote: "In the fourth yere of Queen Elizabeth [1558 $+4=1562]$, John Rose, dwelling in Bridewell, 
devised and made an Instrument, with wyer strings, commonly called the Bandora, and left a son, far excelling himselfe in making Bandoraes, Voyall de Gamboes and other instruments." [italics mine - AH] On this basis Famintsyn claimed that this instrument made its way through Poland into Ukraine where it became very popular.

We know exactly what Rose's bandora looked like and it is obvious that it bears little resemblance to either the kobza or bandura. The English instrument was a cittern, i.e., it had a flat back while the Ukrainian instruments have curved backs. The edges of the former are scalloped while the latter, as a rule, have smooth edges. The bandora had fourteen paired strings over a fretted fingerboard while the strings of the Ukrainian instruments are single. The bandora could be tuned either $\mathrm{G}_{1} \mathrm{C}$ D G B e a or C D G c f a c', while Ostap Veresai tuned the bass strings of his kobza G c d g' $\mathrm{a}^{\prime} \mathrm{d}^{\prime \prime}$. Finally, and this may be the salient difference, the English bandora had no treble strings. Therefore, the only thing the English and Ukrainian instruments have in common is that they are plucked chordophones.

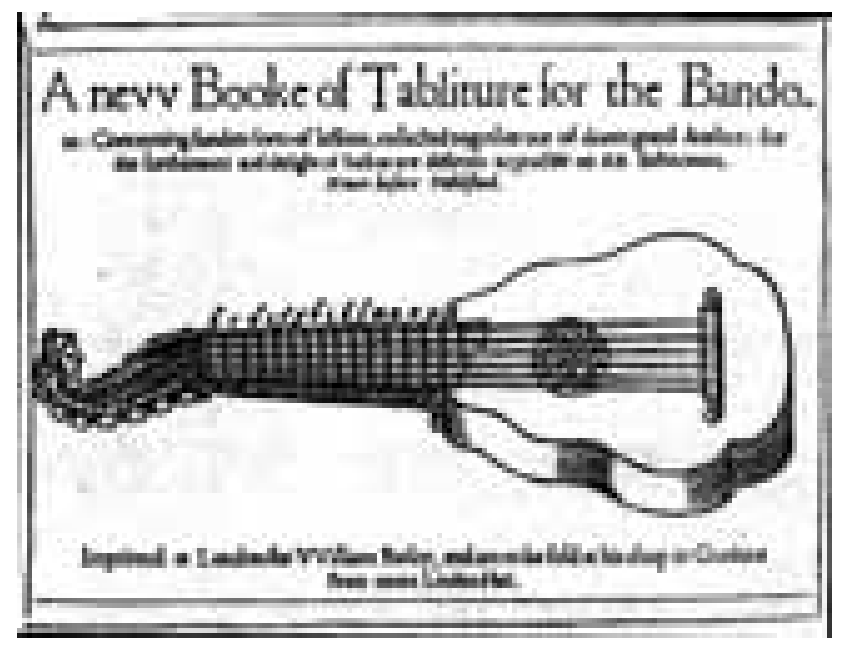

The English bandora. Woodcut from a manual, London, 1596

In his work on Ukrainian folk musical instruments Andrii Humeniuk [153] reproduces an illustration of an instrumental ensemble from Karion Istomin's 1691 Bukvar' [Primer]. Here one can see musicians that play a viol, psaltery, recorder and an unfretted instrument with a round body that has some resemblance to the kobza, but is called a bandura by Humeniuk. Since Karion Istomin's life and work was totally 
connected with Muscovy, this illustration does not warrant much attention in the discussion here.

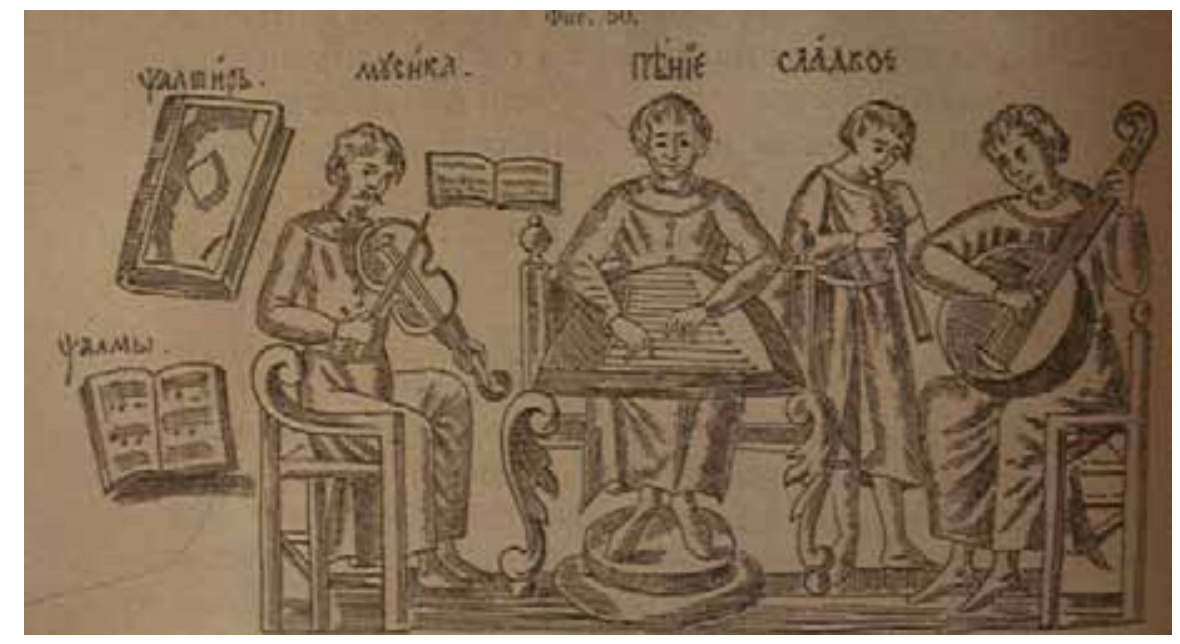

Musicians from Karion Istomin's Bukvar'

At some point, it is difficult to ascertain exactly when, treble strings began to appear on the belly of the kobza and bandura that differentiate these instruments from all others in the lute family. While strings along the neck of a violin or guitar can be stopped to produce the desired pitch, strings on the belly of the Ukrainian instruments can be played only open. From the standpoint of a lute, treble strings are superfluous. One can obtain ever-higher notes simply by stopping the strings ever lower on the neck or soundboard. Additional strings were added sometimes in the bass range, and thus one obtained the archlute, chitarrone or theorbo. These additional bass strings were attached to an additional pegbox, and they would be played open. To be sure, we have a fantastic harp-cittern built ca. 1590 by Vendelin Tieffenbruker in Padua that has a harp-like attachment in the bass range, and treble strings on the belly [Buchner 102]. In the early seventeenth century, similar instruments, called poliphant, were built in England but they had become rarities by 1661 ("Poliphant").

These instruments did not gain widespread popularity either in England or in Italy, and today they are beautiful curiosities in musical instrument museums, while the kobza and bandura thrive in Ukraine. 


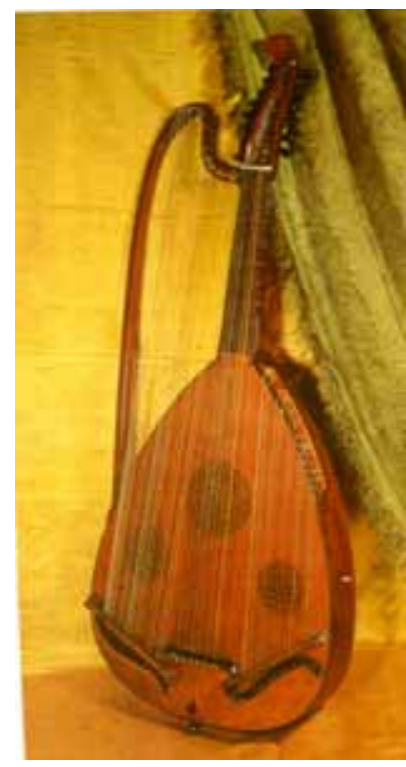

Harp-cittern. Vendelin Tieffenbruker, Padua, 1590 (from Winternitz).

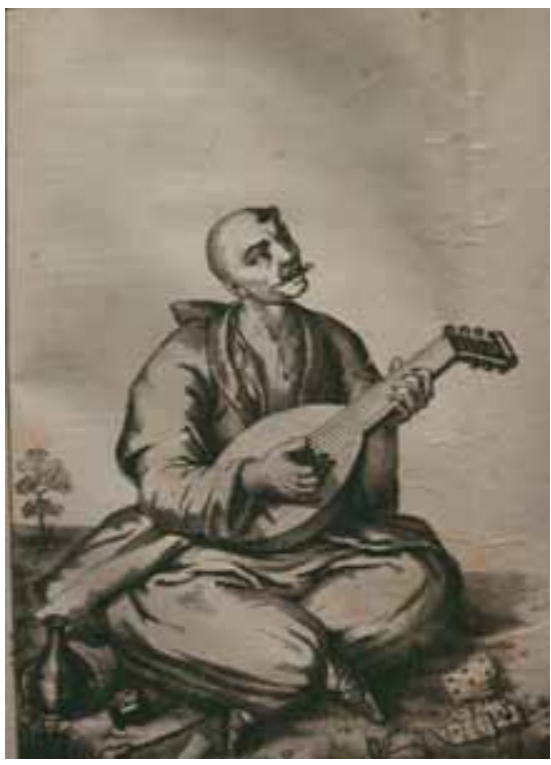

Tymofii Kalyns'kyi, Cossack Playing a Kobza. Fragment of the gravure "Cossacks at Leisure" in Rigel'man

In Soviet times scholars in Ukraine had to quote Famintsyn whose views on the history of the kobza and bandura were thoroughly debunked by Hnat Khotkevych (1930). The tragedy lay in the fact that Khotkevych had been shot by Soviet authorities and his works were proscribed for decades, while Famintsyn became a mandatory source.

\section{The Kobza}

Since we seem to lack firm evidence when treble strings first appeared on plucked chordophones in Ukraine, let us allow that the idea did come from Western or Southern Europe in the sixteenth century. Of course, there is nothing to prevent us from assuming that the idea also could have come independently to a Ukrainian instrument maker. Indeed, Khotkevych [101] unequivocally stated that the treble strings were a Ukrainian invention. The old style instrument without treble strings would continue to be used well into the eighteenth and possibly even nineteenth century. This is amply attested by numerous late-eighteenth and nineteenth century folk paintings of "Kozak Mamai," which show a 
Cossack sitting on the ground with all his gear, usually playing a kobza. (If he is not shown playing it, the instrument is nearby.) There is great variety in the size and shape of these instruments; some have treble strings although a larger number do not, and a small number have frets on the fingerboard. The number of bass strings varies considerably but their number does not seem to exceed seven. Where treble strings are depicted, their number is not greater than that of the bass strings. Here, this instrument will be called kobza.

\section{The Bandura}

Even before the nineteenth century, the number of treble strings increased and a different instrument had evolved - the bandura. Here the melody was no longer obtained by stopping the bass strings of the kobza but on the open diatonically tuned treble strings. The number of bass strings on the traditional (starosvits ' $k a$ ) bandura varied from four to six, usually there were five. The number of treble strings (prystrunky) also varied from thirteen to eighteen, and they were tuned to suit the performer's voice and the character of the piece performed [Kushpet 2007: 40-60]. In the nineteenth century, the bandura continued to evolve adding ever more treble strings.

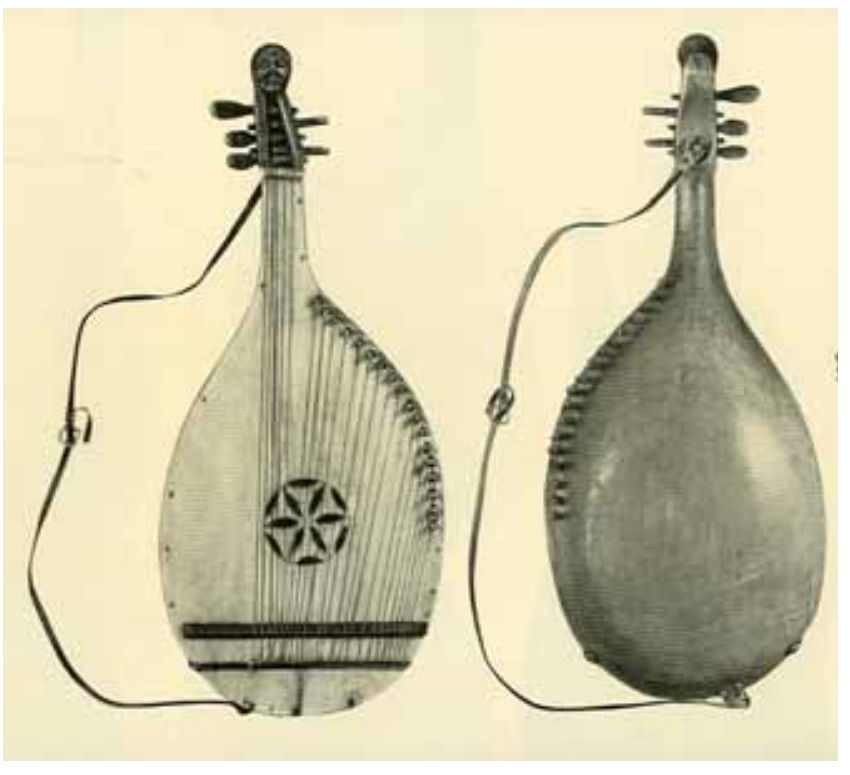

Traditional bandura, 1740 
The Problem

In his enumeration of Ukrainian musical instruments Rigel'man stated that the kobza is a type of bandura [Book. 6, Ch. 38; 4: 87]. The matter was further complicated when, by the nineteenth century, both in folk parlance and scholarly discourse the words kobza and bandura were treated as synonyms, cf., e.g., Ohonovskyi s.v. pó $\rho \mu 1 \gamma \xi$. Furthermore, in the course of the nineteenth century the number of treble strings on the bandura continued to expand while those on the kobza remained constant and the instrument itself was losing popularity and, for all practical purposes, died out with the demise of Ostap Veresai (1803-1890). One could think that the matter would be closed; the bandura could simply acquire an alternate name - kobza.

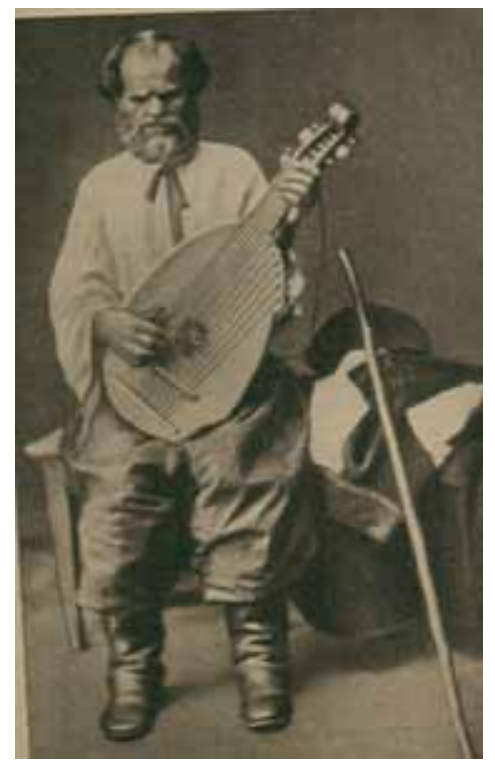

Ostap Veresai and his kobza

But his was not to be. Many folk instrument orchestras appeared in the Ukrainian SSR, although, in many of them, the instruments used were not quite the ones that actually were or had been used by the folk. Such non-Ukrainian instruments as the dom(b)ra were incorporated into these ensembles. This instrument could have either three strings tuned, depending on the size, B E A or E A D, or four tuned to G D A E. Eventually, these instruments were seen as something of an embarrassment because obviously they were not Ukrainian and 
something had to be done with them. Without changing the tuning, thus requiring no retraining of the performers, the body of these reconstructed kobzas was modified to reflect the shape of instruments that were depicted on the aforementioned folk pictures of Kozak Mamai. In his website (http://kobza.ukrbiz.net/) the manufacturer clearly states:

To the degree possible, I shall try to tell everything that I know about this instrument inasmuch as I myself created it some ten years ago when I was working in the enterprise "Zoloti ruky." This firm has produced a complete series of instruments designed by Professor [Mykola Antonovych] Prokopenko, and then approved and curated by the Ministry of Culture of Ukraine. The instrument got a name full of pathos - KOBZA.

What does this instrument have in common with legendary kobza, the kobzar [kobza players] instrument of yore? I think only the name and ambitions. Regardless, this is an attempt to replace the dombra as the fundamental orchestral string folk instrument in Ukrainian folk collectives. And so, prima, alto, tenor, bass and contrabass instruments have been made with this name, as well as a six-string kobza with guitar tuning. [My translation from the Russian - AH]

Indeed, these instruments have found a place even in the National Bandurists Cappella of Ukraine, but not as equals. They were in back rows, and when bandura players would turn their instruments toward the audience during applause, the kobza players lowered their instruments, as if they were ashamed of them. At least that was the picture during the cappella's Canadian tour in 1988.

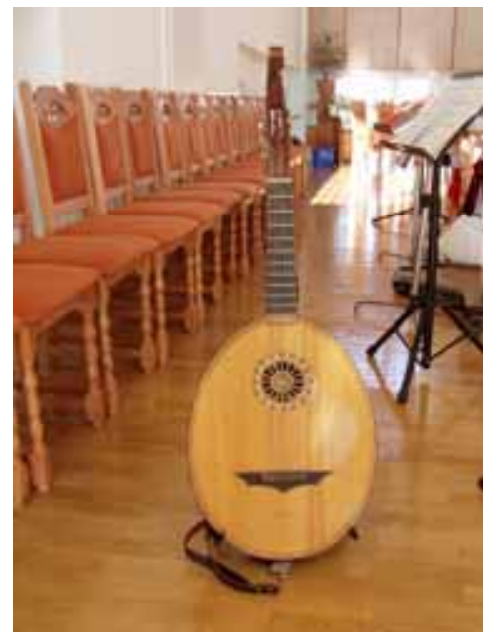

Six-string kobza used in the National Bandurists Cappella of Ukraine

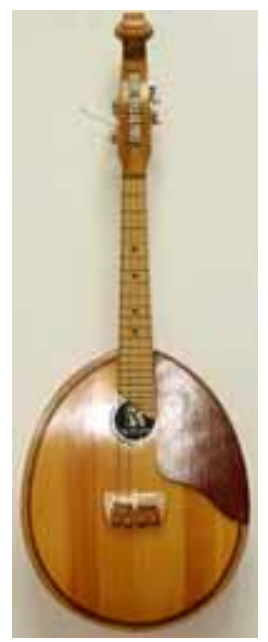

Four string modern kobza 


\section{The Modern Bandura}

There was a degree of asymmetry in the traditional bandura, but as more and more treble strings were added this started posing a problem. Finally, young Khotkevych had a bandura constructed in 1894 with the neck strongly shifted to the performer's right thus allowing much more room for treble strings. Khotkevych claimed that this was "the first change in the folk instrument" [129]. In reality, however, some asymmetrical banduras had been constructed earlier in the nineteenth century [Kushpet 2007 unpaginated illustrations]. This allowed for an ever-larger number of strings. At first, the tuning remained diatonic but within a few decades attempts were made to allow the performer to play in a greater number of keys.

In one system, this was achieved with a mechanism of a system of ditals mounted on the bridge that allowed each string to be retuned up or down by exactly one semitone. In the majority of cases, this allowed the bandurist to play in all the keys between E-flat major (c minor) and $\mathrm{E}$ major (c-sharp minor). Another system used additional strings placed between the diatonic ones for all the intervening semitones. These would be mounted on a plane that intersected the diatonic range, so that the diatonic range would be on top near the bridge, but the semitones would be at the top of the instrument's belly. Finally, both systems were combined but now the retuning mechanism is placed at the top of the belly. The mechanism is ganged, and the movement of one lever sharps both the fundamental string and its semitone. This system allows the performer to play in all keys between C-flat major (a-flat minor) and Csharp major (a-sharp minor). Conservatory-trained performers favour this concert type of instrument.

Some bandurists, however, felt that this evolution distorted the instrument and detached it from its roots. They yearned for a more authentic bandura on which the ancient repertoire - proscribed under the Soviets - could be performed. Although the form of the instrument was well know, the playing technique would have been lost had it not been for the architect Heorhii Tkachenko who had mastered it in his youth, and in the late twentieth century was able to teach young enthusiasts to build and play this instrument. 


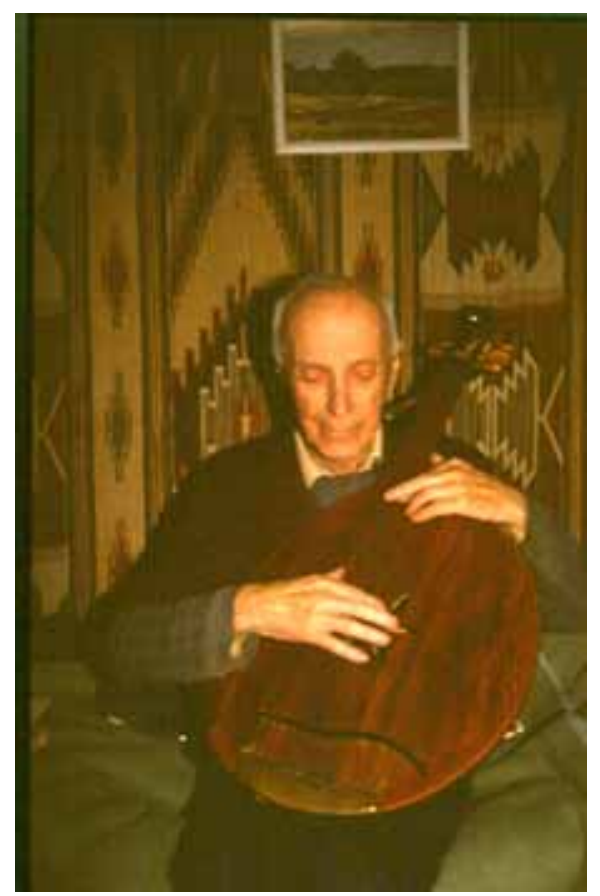

Tkachenko playing a traditional bandura.

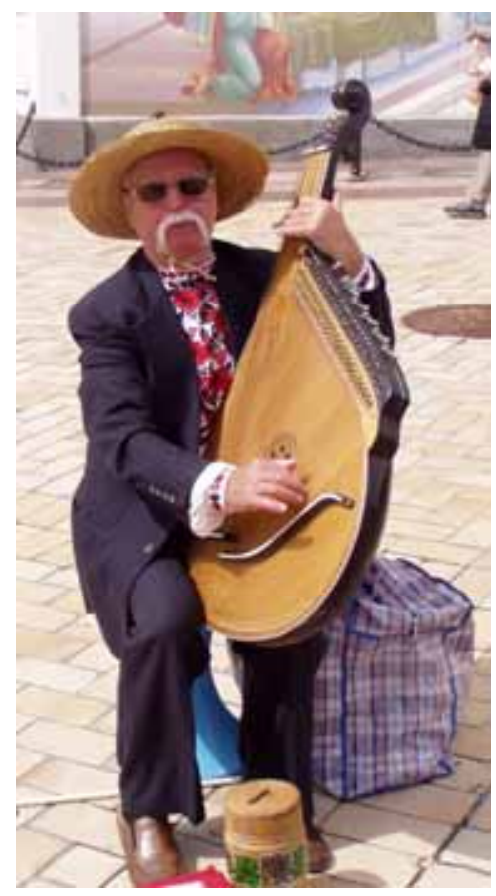

Pavlo Suprun playing a concert type bandura.

The Kobza Reborn

Fortunately for posterity, the composer and ethnomusicologist Mykola Lysenko (1842-1912) made an accurate record of Ostap Veresai's kobza, playing technique and repertoire. Although none of the latter's instruments have survived to our day, Lysenko's publication (1955) on the subject allowed the reconstruction of the instrument. Beginning with the 1980s, several enthusiasts, Volodymyr Kushpet, Mykhailo Khai and Mykola Budnyk among them, have reconstructed Veresai's kobza and his repertoire. They also composed new material using this instrument for accompaniment [Cherkas'kyi 108]. Soon thereafter, Kushpet published an instruction manual for the kobza, old style bandura, and torban (1997). Far from being a one-man operation, the reborn kobza has a number of disciples who continue and develop this tradition. 


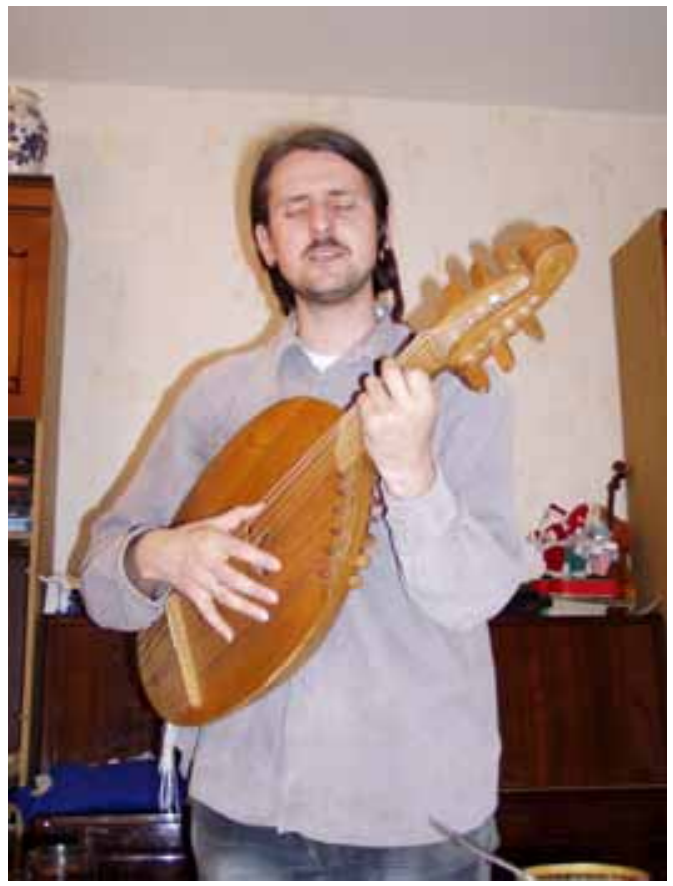

Taras Kompanichenko playing on a

Veresai type kobza.

Conclusions

As a concert instrument taught in the Kyiv and L'viv conservatories, the bandura has become standardised. Unlike in the nineteenth century, when every performer would tune the instrument to suit the tessitura of a song to his voice range, the modern instrument has a set tuning. Likewise, the number of strings is fixed, although there are different size instruments with fewer strings constructed especially for children. In diatonic instruments, the number of strings is around 32, in chromatic instruments around 55, and in concert instruments it is around 65. Of those, the number of bass strings varies from eight (diatonic instrument) to fifteen (L'viv concert bandura). (We say "around" because there are subtle differences between instruments made in the Chernihiv and L'viv musical factories.) Obviously, the number of treble strings in each case is much larger than the bass strings. All strings on the bandura, whatever the model, are played open, i.e., they are not stopped to alter the pitch. As a general rule, the melody is played on the treble strings. 
The modern kobza has an equal number of bass and treble strings. (The term "modern kobza" may be a misnomer because contemporary instruments are faithful reconstructions of Veresai's instrument.) The melody is played primarily on the six bass strings (tuned G C D g a d') that are stopped on the unfretted fingerboard to produce the desired note. The treble strings are tuned diatonically $\mathrm{g}^{\prime} \mathrm{a}^{\prime} \mathrm{b}^{\prime} \mathrm{c}^{\prime \prime} \mathrm{d}^{\prime \prime} \mathrm{e}$, , and can be used in bandura style [Kushpet 1997: 7-80).

Will the re-emergence of the traditional kobza put an end to the onomastic confusion between the kobza and bandura that has obtained through the twentieth century? Only time will tell.

\section{BIBLIOGRAPHY}

Buchner, Alexander 1980. Colour Encyclopedia of Musical Instruments. London: Hamlyn.

Cherkas'kyi, Leonid 2003. Черкаський, Леонід. Украӥнські народні музичні інструменти [Ukrainian Folk Musical Instruments]. Київ: Техніка.

Diagram Group 1978. Musical Instruments of the World. New York: Bantam Books.

Famintsyn, Aleksandr 1891. Фаминцин, Алексарндр. Домра́ u сродные ей музыкальные инструменты русского народа: балалайка - кобза - бандура - торбан-гитара [The Domra and Similar Musical Instruments of the Russian People: Balalaika Kobza - Bandura - Torban - Guitar]. Санкт-Петербург: Тип. Э. Арнольда.

Harkavy (aka Garkavi), Al’bert [Avraam] Iakovlevich 1870. Гаркави, Альберт (Авраам) Яковлевич. Сказания мусульманских писателей о славянах и русских (C половины VII века до кониа $X$ века по P. Хр.) [Narratives about the Slavs and Rus'ians [as Presented] by Muslim Writers (From the Middle of VII Century Through the End of the X Century A.D.). Санкт-Петербург: Императорская академия наук.

Humeniuk, Andrii 1967. Гуменюк, Андрій. Украӥнські народні музичні інструменти [Ukrainian Folk Musical Instruments]. Київ: Наукова думка.

Ibn Faḍlān, Ahmad 2005. Ibn Fadlan's Journey to Russia: A Tenth Century Traveler from Baghdad to the Volga River. Translated with commentary by Richard N Frye. Princeton: Markus Wiener Publishers. 
Khotkevych, Hnat 1930. Хоткевич, Гнат. Музичні інструменти українського народу [Musical Instruments of the Ukrainian People]. Харків: ДВУ.

http://kobza.ukrbiz.net/

Kushpet, Volodymyr 1997. Кушпет, Володимир. Самовчитель гри на старосвітських інструментах. Кобза О. Вересая, Бандура Г. Ткаченка, Торбан Ф. Відорта [Self-Instruction Manual for Playing Ancient Instruments. O. Veresai's Kobza, H. Tkachenko's Bandura, F. Vidort's Torban]. Київ: LitSoft.

Kushpet, Volodymyr 2007. Стариівство: Мандрівні співиі-музиканти в Україні (XIX - поч. XX $\mathrm{cm}$.) [Minstrelsy: Travelling Singers-Musicians in Ukraine (XIX - Beginning of the XX Centuries]. Київ: Tempora.

Lysenko, Mykola 1955. Лисенко, Микола. Характеристика музичних особливостей українських дум і пісень виконуваних кобзарем Bepecaєм [The Characteristic Musical Features of Ukrainian Epics and Songs as Performed by the Minstrel Veresai]. Київ: Мистецтво.

Ohonovskyi, Ilarion 1900. Огоновський, Іларіон. Словар до Гомерової Одиссеї $і$ Ілїяди [The Vocabulary of Homer's "Odyssey" and "Iliad"]. Львів: Наукове Товариство імени Шевченка.

"Poliphant." The New Grove Dictionary of Music and Musicians. 2d edition. New York: Grove's Dictionaries, 2001.

Rigel'man, Aleksandr 1847. Ригельман, Александр. Летописное повествование о Малой России и ее народе и козаках вообще ... [Chronicle about Little Russia and Its People, and about the Cossacks in General...] Москва: Императорское общество истории и древностей российских.

Siarczyński, Franciszek 1843-58. Obraz wieku panowania Zygmunta III, króla polskiego i szwedskiego ... [Description of the Reign of Zygmunt III, King of Poland and Sweden]. Poznań: Nowa księga.

Simocatta, Theophylactus 1986. The History of Theophylact Simocatta. An English Translation with Introduction and Notes [by] Michael and Mary Whitby. Oxford: Clarendon Press.

Stow, John 1615. The Annals, or, General Chronicle of England / begun first by maister John Stow; and after him continued and augmented with matters forreyne and domestique, auncient and moderne vnto the ende of the present yeere 1614 by Edmond Howes ... London: Thomas Adams.

Winternitz, Emanuel 1967. Musical Instruments of the Western World. Photographs by Lilly Stunzi. New York - Toronto: McGraw-Hill Book Company. 